\title{
Transient diabetes mellitus secondary to L-asparaginase
}

\author{
Lalaine Audrey G Matitu-Untalan \\ From 7th APPES Biennial Scientific Meeting \\ Nusa Dua, Bali. 14-17 November 2012
}

Secondary Diabetes Mellitus (DM) has been associated in about $1-14 \%$ of patients with hematologic malignancy treated with L-asparaginase. An 11-year old Filipino female, diagnosed with Acute Lymphoblastic Leukemia, developed hyperglycemia associated with polyuria and polydipsia while on-going induction chemotherapy. There was no family history of diabetes mellitus. Chemotherapy drugs included L-Asparaginase, Prednisone, Vincristine and intrathecal methotrexate using the LIC protocol. Among these agents, Prednisone and L-Asparaginase are known to cause hyperglycemia. Given the risk, the patient was monitored by checking for glucosuria at least once a week. The L-asparaginase was started on Day 8 of chemotherapy after one week of Prednisone given at $60 \mathrm{mg} / \mathrm{kg} / \mathrm{m}^{2}$. No glucosuria was noted prior to the start, as well as during the first week of chemotherapy. On Day 16 of chemotherapy, after 4 doses of L-Asparaginase at $6000 \mathrm{u} / \mathrm{m}^{2} 3 \mathrm{x}$ a week, she developed epigastric pain, vomiting, polyuria, excessive thirst, hyperglycemia and glucosuria $(+4)$. Arterial blood gas was normal and negative for urine ketones. Serum amylase and lipase were likewise normal. The Random blood sugar was $680 \mathrm{mg} / \mathrm{dL}$ $(37.4 \mathrm{mmol} / \mathrm{L})$. Upon repeat the next day, it was $619 \mathrm{mg} / \mathrm{dl}$ and $\mathrm{HbA} 1 \mathrm{c}$ at $7.4 \%$. Regular insulin started at a dose of $0.8 \mathrm{unit} / \mathrm{kg} /$ day given every six hours which was later increased to 1 unit $/ \mathrm{kg} /$ day. The patient was maintained on pre-mix Insulin (70\% isophane/ 30\% regular) at 1.2 unit $\mathrm{per} / \mathrm{kg} /$ day with good control of blood sugar between 100 $200 \mathrm{mg} / \mathrm{dl}$. L-Asparaginase was completed for 9 doses. The patient required tapering doses of insulin therapy for one month after the last dose of L-Asparaginase. After discontinuation of insulin, blood monitoring for two more weeks showed no recurrence of hyperglycemia and the associated symptoms.

Philippine General Hospital, Philippines
Inhibition of insulin and insulin receptor synthesis, leading to a combined insulin deficiency and resistance syndrome, is the supposed mechanism of the L-asparaginase effect. The temporal relationship of the appearance and resolution of hyperglycemia with the L-Asparaginase administration and discontinuation respectively, is the strong basis for attributing the transient DM to the said agent rather than to steroids. However, the risk and severity of DM increases when L-asparaginase and steroids are used concomitantly. Close monitoring of the blood sugar levels of such patients is emphasized.

Published: 3 October 2013

doi:10.1186/1687-9856-2013-S1-P22

Cite this article as: Matitu-Untalan: Transient diabetes mellitus secondary to L-asparaginase. International Journal of Pediatric Endocrinology 2013 2013(Suppl 1):P22.

Submit your next manuscript to BioMed Central and take full advantage of:

- Convenient online submission

- Thorough peer review

- No space constraints or color figure charges

- Immediate publication on acceptance

- Inclusion in PubMed, CAS, Scopus and Google Scholar

- Research which is freely available for redistribution (c) 2013 Matitu-Untalan; licensee BioMed Central Ltd. This is an Open Access article distributed under the terms of the Creative Commons Attribution License (http://creativecommons.org/licenses/by/2.0), which permits unrestricted use, distribution, and reproduction in any medium, provided the original work is properly cited. 